\title{
The Impact of Social Responsibility Performance on the Value Relevance of Financial Data in the Banking Sector: Evidence from Poland
}

\author{
Piotr Bolibok (1)
}

check for updates

Citation: Bolibok, P. The Impact of Social Responsibility Performance on the Value Relevance of Financial Data in the Banking Sector: Evidence from Poland. Sustainability 2021, 13, 12006. https://doi.org/10.3390/ su132112006

Academic Editor: Andrea Pérez

Received: 21 September 2021

Accepted: 28 October 2021

Published: 29 October 2021

Publisher's Note: MDPI stays neutral with regard to jurisdictional claims in published maps and institutional affiliations.

Copyright: (C) 2021 by the author. Licensee MDPI, Basel, Switzerland. This article is an open access article distributed under the terms and conditions of the Creative Commons Attribution (CC BY) license (https:/ / creativecommons.org/licenses/by/ $4.0 /)$.
Department of Economic Policy and Banking, The John Paul II Catholic University of Lublin, Al. Racławickie 14, 20-950 Lublin, Poland; piotr.bolibok@kul.pl

\begin{abstract}
Corporate social responsibility (CSR) is inevitably becoming an increasingly important part of almost every business. This is particularly true for the banking industry, which suffered substantial losses in reputation and public trust in the aftermath of the global financial crisis. Not surprisingly therefore, banks around the world have visibly intensified their CSR efforts. One of the key dimensions of CSR regards the reliability and transparency of a firm's communication with the market, which suggests that information disclosed by responsible companies may be more value relevant. The related evidence, especially in the banking sector, is however modest and mixed. The paper aims, therefore, at empirical investigation of the impact of social responsibility performance on the value relevance of financial data in the Polish banking sector. The research employs multivariate regression analysis based on the Ohlson model and the Chow test for structural breaks. The examined sample covers 154 bank-year observations of 17 banks listed on the Warsaw Stock Exchange from 2009-2020. The results suggest that financial disclosures of banks included in CSR indices are generally more value relevant. Additionally, more responsible banks exhibit higher (lower) responsiveness of market values to net earnings (book values of equity) compared to their less socially responsible counterparts.
\end{abstract}

Keywords: banks; value relevance; financial data; book values; earnings; Ohlson model

\section{Introduction}

The recent years have brought a significant increase in the interest in corporate social responsibility (CSR) and performance (CSP) on the part of all major stakeholder groups, including, in particular, equity investors, managers, and regulators. The concept of CSR extends the responsibility of companies beyond the interest of their owners to other societal stakeholders, including employees, consumers, government, community, and the natural environment, whereas CSP focuses on actual results achieved in the area of social responsibility [1].

CSR encompasses a wide range of proactive and reactive activities focused on both internal and external factors aimed at enhancing the economic, social, and environmental performance of enterprises, with respect to stakeholder expectations [2]. The above factors, ranging from external regulatory and market pressures to the individual sense of moral obligation, have gradually become crucial determinants of modern firms' behavior [3].

Being institutions whose existence and viability are almost entirely dependent on public trust in them, banks should naturally be inclined to follow the path of social responsibility and engage in CSR-related activities even more frequently and deeply than other businesses. Since banks are inherently more exposed to the risk of reputation than other industries, they are also more vulnerable to criticism from their stakeholders and customers [4]. Not surprisingly, therefore, they are highly sensitive to environmental, social, and governance (ESG) risk, as it may directly affect both their financial performance [5] and an overall operational risk exposure [6]. 
Given the role of banks as leading financial intermediaries and the worldwide interconnections between them, the scale of banks' social impact is undoubtedly meaningful. The results of their activities affect not only the well-being of their owners, employees, and clients, but also society as a whole through participation in the processes of capital accumulation and allocation and the impact of the banking sector's financial soundness and stability on the entire economy. Social responsibility of banks involves both the responsibility of individual institutions for the security of funds entrusted to them and the responsibility of the entire banking sector for the stability of the financial system and the economy. Moreover, the long-term nature of many bank products and services leads to the emergence of a complex system of relatively persistent relationships between them and their external stakeholders [7]. The business goals of banks should therefore not be reduced to the maximization of the benefits of their owners, but also encompass the needs of other stakeholders, and society as a whole. Given the above, banks should be more motivated to include the social responsibility dimension in their business decisions and to disclose information on the extent and actual outcomes of the undertaken actions [8]. Engagement in socially responsible activities offers banks additional opportunities to distinguish themselves from competitors and to improve the perceived quality of their services in the eyes of the public [9] (p. 45).

As pointed out by Zioło [5] (p. 186), banks generally respond to the challenges of social responsibility with a certain delay in comparison with the real sphere. In fact, the social performance of the banking sector gained a special importance in the aftermath of the global financial crisis (GFC), which was caused largely by irresponsible behavior of banks that massively exploited moral hazard to achieve their economic goals. The recordhigh fines imposed by the regulators for the revealed misconduct forced the banking industry to restore the public's trust and to develop new, more transparent business models, incorporating social responsibility as an integral component of their strategies.

Although more than a decade has passed since the onset of the GFC, the results of the recent 2021 Edelman Trust Barometer report indicate that despite some improvement, the financial services sector still remains the least-trusted industry. On average only $52 \%$ of more than 33,000 respondents from 28 countries declared trust in it, which is 7 percentage points less than the second-worst-trusted entertainment sector, and 16 percentage points less than the leading technology sector [10] (p. 47).

It is also worth pointing out that due to significant explicit and implicit costs involved, a successful implementation of the principles of social responsibility and sustainability in banks' business models often depends on the soundness of their financial position [7]. In fact, there is strong feedback between banks' financial position and their social performance. On the one hand, long-run profitability that ensures banks' financial soundness depends on the key components of the CSR framework, such as compliance with ethical and sustainability standards, transparency of products and operations, and reliability of financial disclosures. On the other hand, public trust in banks, their reputation, and long-run viability are strongly determined not only by the perceived ethicality and responsibility of their business practices, but also their financial standing. These two-directional linkages strongly expose banks to a wide range of CSR-related opportunities and threats. Notwithstanding the above, the evidence from transition economies [11] suggests, however, that even banks with lower profitability may exhibit strong engagement in socially responsible activities.

One of the key areas of CSR regards the quality and transparency of the disclosed information. In general, socially responsible companies are expected to provide the public, and in particular equity investors, with the most comprehensive and reliable data. This issue appears to be particularly important in the case of banks, whose business models are usually highly complex and opaque [12] (p. 779).

A better access to reliable and value relevant information should contribute to limitation of investors' uncertainty about the expected economic performance of socially responsible banks, and to reduction of the required risk premia. This, in turn, ceteris paribus, would lead to increases in the perceived market values of such banks. More 
informed equity investors and stock market analysts should also be able to estimate the intrinsic value of responsible banks more accurately [13], thus improving the overall efficiency of the capital market in that area. From this perspective, compliance with CSR principles may become an important element of listed banks' business strategies aiming at sustainable growth of their market values.

Attempting to restore the sector's reputation, largely damaged by unethical and irresponsible business practices that ultimately led to the GFC, banks around the world have become increasingly active in the area of CSR and its reporting [14]. This, in turn, greatly enhances the possibilities of empirical investigation of the impact of CSP on banks' market value and the value relevance of their disclosures.

As regards the Polish banking sector, until recently, the majority of banks did not exhibit significant engagement in socially responsible activities, nor did they report on their results in a systematic manner. Smaller banks usually do not disclose any information regarding such activities or provide it only occasionally and in a very reduced form. In fact, incorporation of the CSR principles into actual business models and comprehensive sustainable reporting appears to be concentrated in a relatively small group of leading financial institutions, especially listed banks, which seems to recognize the importance of both CSR engagement and its importance to their stakeholders [15]. As demonstrated by Krasodomska [16], the vast majority of listed banks disclose CSR-related information in management commentaries. Although the extent and detailedness of the disclosures vary across different institutions, the overall quality of banks' social reporting seems to be improving over time.

Despite the ever increasing interest on the part of academic researchers and practitioners, the understanding of the impact of CSP on fulfilment of strategic goals, financial performance, market value, and the value relevance of financial disclosures is still imperfect, both in the theoretical [17] as well as in the empirical dimension [18]. The results of empirical studies seem to be largely ambiguous. Some authors argue that the above impact is positive $[19,20]$, while others claim exactly the opposite [21,22]. These discrepancies might be explained from at least two perspectives. First, CSR is a complex and multidimensional construct, encompassing not only the actions taken up due to altruistic motives, but also the entire array of issues pertaining to working conditions, human rights, equality, or internalization of enterprises' societal and environmental impact. This, in turn, causes objective difficulties in defining this concept, which largely limits the comparability of individual results and possibilities of their generalization. Second, the link between corporate social and financial performance might in reality be much more 'illusory' than suggested by the body of research [23], in particular due to still insufficiently developed theoretical foundations justifying its existence, e.g., [24,25].

Direct empirical evidence on the relationship between social and financial performance of banks, and in particular on the impact of CSP on their market values and perception of the disclosed financial information by the equity investors is relatively limited and mixed [26-44]. Moreover, to date only a few studies in the relevant international literature have investigated the impact of CSP on the value relevance of accounting data in a cross section of industries [45-49] or the specific context of the banking sector [50-52].

Given the above, the present paper aims to enhance the existing international literature by investigating the impact of CSP on the value relevance of key accounting variables reported by the domestic banks listed on the Warsaw Stock Exchange (WSE) over the period 2009-2020. By employing multivariate regression analysis based on the Ohlson [53,54] valuation model and the Chow test for structural breaks, the study attempts to compare the value relevance of book values of equity and net earnings in banks included in the CSR indices of WSE (Respect Index and WIG-ESG) with that of other publicly traded banks in the Polish banking sector. Consistent with the results of studies conducted in other settings, e.g., [45-49,52,55-57] the results suggest that banks with better CSP exhibit markedly higher value relevance of financial data than their less socially responsible counterparts. Additionally, in line with several prior investigations conducted in developed 
markets $[45,47,49,51,52]$, more responsible banks listed on WSE demonstrate higher (lower) sensitivity of market values to net earnings (book values of equity).

The remainder of the paper is organized in five sections. The next section provides a review of the existing international literature on the linkages between corporate social and financial performance and their implications for valuation of listed companies, with a particular focus on the banking sector. The methodological framework of the paper and the data selection procedures are outlined in Section 3. Section 4 presents the empirical findings of the study. The discussion of the results and main limitations of the study are provided in Section 5. The paper is closed with conclusions summarizing its key findings and contributions along with some suggestions for future research.

\section{The Literature Review}

\subsection{The Linkages between Corporate Social and Financial Performance and Their Value Relevance}

The concept of CSR promotes the view that modern businesses should focus not only on the benefits of their owners, but simultaneously acknowledge the needs of a wide array of various stakeholders [58]. The actual results of socially responsible activities are recognized as CSP [1]. In recent years, both CSR and CSP have attracted growing attention from equity investors, gradually becoming an important factor affecting their capital allocation decisions [59].

Diverse stakeholders increasingly expect that enterprises should accept responsibility for the direct and indirect impact of their activities on the natural environment and society. On the one hand, in a world where the primary goal of a typical business is to maximize shareholders' wealth, a firm ought to engage in socially responsible activities if, and only if, they are expected to create value $[60,61]$. On the other hand, however, in order to achieve such growth in value, a company should disclose additional information enabling the equity investors to assess its performance in that area. This issue is particularly important for the listed companies as disclosure of value relevant data enables them to reduce the information asymmetry inevitably existing between the management and the equity investors.

Corporate communication of CSP typically takes the form of sustainability reports [62]. The willingness of companies to provide stakeholders with reliable, comprehensible, and up-to-date information both on their engagement in socially responsible activities (via sustainability reporting) [63] as well as on their actual financial position (via financial reporting) constitutes one of the key dimensions of CSR. Therefore, the efficiency and reliability of firms' communication with the public becomes a central area of their social performance.

In parallel, sustainability indices, such as the Dow Jones Sustainability United States Index, FTSE4Good, or WIG-ESG of the Warsaw Stock Exchange, have been developed to provide equity investors with further insight into listed companies' CSP [64]. Inclusion in such indices is usually considered to be a significant accomplishment for a given firm, since it reflects endorsement of its sustainability practices by an independent, respectable external institution [65].

Despite the relatively abundant literature, the issue of the value relevance of CSR has not been definitely settled [50]. Some authors find CSR to be value relevant on the basis of the impact of CSR-related disclosures on stock returns $[66,67]$ or their incremental explanatory power over accounting variables in valuation models [63,68-71]. Although many studies demonstrate that equity investors positively value CSR-related disclosures [69,70,72], others report negative influence of such information on market value [73]. Lastly, the results of many studies suggest that CSR and the related information disclosures are value relevant only in some market settings, industries, or stages of the business cycle, while in the others they seem to exert an insignificant impact on firms' market value, see e.g., [45,63,69,74].

The results of empirical research suggest that the quantity and quality of CSP-related information disclosed by listed companies is partly determined by the cost of equity. Since this cost depends largely on the reliability and transparency of the available information [75], firms with relatively costly equity, such as banks, tend to be more inclined to report their 
social performance, aiming at its reduction [76]. In fact, according to Gregory et al. [77], a seemingly positive relationship between firms' social performance and their market values may result exactly from an ability to decrease the cost of equity.

According to Ioannou and Serafeim [78], better CSP contributes to more favorable recommendations of stock market analysts. Interestingly, however, Lee et al. [79] reported an inverse relationship between the supply of CSR-related information and the value of analysts' recommendation revisions, which suggests that a richer information environment makes it more challenging for analysts to issue valuable recommendations.

Robinson et al. [65] argue that a reputation for being committed to CSR might be perceived as an intangible asset allowing a given firm to increase the value and/or decrease the volatility of expected cash flows. According to Cabral [80], such reputation is an important source of sustained competitive advantage and also serves as a 'cushion' against unfavorable market developments. This view seems to be consistent with the findings of Flammer [81], who demonstrated that better CSP stimulated the growth of a firm's market value while socially irresponsible behavior tended to decrease it. In fact, it is likely that the latter relationship is simply a reflection of a more general, positive correlation between a company's engagement in CSR-related activities and its financial performance [82].

In an extensive study, Kaspereit and Lopatta [83] examined the 600 largest European companies over the period 2001-2011 to determine whether relative corporate sustainability, as measured by the SAM sustainability ranking and reporting in accordance with GRI application levels, results in higher market valuation of their shares. They reported an overall positive association between corporate sustainability and market value, thus supporting the view that complying with social responsibility principles might be treated as a shareholder value-increasing business strategy.

In a similar vein, Miralles-Quiros et al. [84] investigated whether sustainability leadership, as proxied by inclusion in the DJSI Europe index, was value relevant for the investors in ten major European stock markets. Their results indicate that overall sustainability leadership is value relevant; however, its positive impact on firm value is statistically significant only in Germany and Sweden.

Several studies in the international literature have also explored the impact of CSP on the value relevance of accounting information disclosed by listed companies. Intuitively, more socially responsible firms are expected to provide their stakeholders, and primarily equity investors, with more reliable and value relevant accounting disclosures. Additionally, as pointed out by Koller [85], corporate sustainability efforts might be perceived as strategic investments of positive net present value in the long run. The related mitigation of regulatory risk and/or increase in profits from socially responsible activities may, therefore, result in higher valuation of company earnings, provided that a proper quality of sustainability reporting is ensured.

According to Kim et al. [55], socially responsible companies are less inclined to manage earnings through discretionary accruals or manipulate their real operating activities, and thus they are more likely to produce high-quality and value relevant financial reports. In a similar vein, Choi and Pae [56] demonstrated that corporate commitment to business ethics resulted in a more conservative earnings reporting, limited earnings management practices, and improved the accuracy of cash flow forecasts, leading to a higher quality of future financial reporting. In a recent study on the interactions between mandatory adoption of IFRS and CSR, Hsu and Chen [57] reported that CSR engagement improved the overall transparency of financial reports, limiting earnings manipulation, increasing quality of accruals and predictability of earnings, and leading to lower analyst forecast errors. They also found some limited evidence of a positive impact of CSR on the value relevance of key accounting items, i.e., net earnings and book values of equity.

Cormier and Magnan [45] examined the impact of environmental reporting on the relationship between earnings and market value of companies from Canada, France, and Germany and reported that only in the latter case was such impact significantly positive, while in the others environmental information did not seem to affect the value relevance 
of earnings. In turn, according to Reverte [48], CSR-related disclosures by Spanish listed companies increased the value relevance of both net earnings and book values of equity, especially in environmentally-sensitive industries.

Lourenço et al. [46] demonstrated that the companies included in the Dow Jones Sustainability United States Index (DJSI US), which have a reputation for sustainability leadership, reveal significantly higher value relevance of net operating income than their less socially responsible counterparts. The study reports also an analogous, however not significant, effect for book values of equity. In a similar vein, Sutopo et al. [47] examined the relationship between CSR-related disclosures and the value relevance of accounting information by comparing the Sustainability Reporting Award (SRA) winners with other firms over the period 2008-2016. Their findings indicate that financial disclosures by SRA winners were generally much more informative in terms of explaining the variance in market value. Moreover, SRA winners revealed a higher (lower) positive association between reported earnings (book values) and stock returns than their counterparts.

In a recent multi-country study of the EU-listed companies, Dimitropoulos and Koronios [49] reported that although corporate environmental responsibility alone did not significantly affect firms' market values, it had a moderating impact on the value relevance of accounting numbers. In particular, more responsible companies exhibited higher persistence and predictability of earnings, as well as positive influence of reported profits and common equity figures on their stock prices.

\subsection{The Impact of CSP on the Financial Performance and Valuation of Banks}

\subsubsection{The Evidence from Developed Markets}

Direct empirical evidence on the relationship between social and financial performance of banks as well as on the value relevance of CSR in the banking sector seems relatively limited, since in the majority of related studies financial institutions are either excluded from the examined samples due to their specificity or analyzed jointly with companies from other industries. Additionally, just as in the case of other industries, the results of empirical studies are generally mixed.

In one of the pioneering studies, Simpson and Kohers [26] demonstrated a significant positive association between social and financial performance of U.S. commercial banks in the early 1990s. In particular, they reported that more socially responsible banks exhibited, on average, a higher return on assets and lower loan losses ratios than their less socially performing counterparts.

Cheung and Mak [27] investigated the association between CSR disclosures and financial performance in an international context of 57 banks from 19 countries, and concluded that there is no definite relationship, either positive or negative. Similar results have been reported for international and Italian banks by Soana [28], while Chich et al. [29] examined more than 500 financial entities from 34 countries and failed to find a statistically significant association between social responsibility and financial performance. Additionally, they argued that CSR orientation was more pronounced for larger firms, and those operating in countries with stronger legal enforcement, more co-operative relations between employers and employees, higher-quality management schools, and more favorable macroeconomic conditions. Surprisingly, however, engagement in CSR-related activities appeared to be less intensive in countries with stronger shareholder rights.

In turn, Wu and Shen [31] reported a positive relationship between social and financial performance for a sample of 162 banks from 22 countries over the period 2003-2009. In particular, their evidence suggests that CSR is positively associated with interest and non-interest income, return on assets (ROA), and return on equity (ROE), whereas its relationship with non-performing loans is negative. These findings seem to corroborate the view that banks tend to engage in CSR-related activities for strategic reasons, as it enables them to perform better with respect to both profitability and credit-risk exposure.

In a similar vein, Gangi et al. [9] examined a sample of 72 European commercial banks over the period 2009-2015 and reported a positive impact of CSR on both profitability 
and loan portfolio quality. Their findings also suggest that CSR engagement is positively correlated with bank size and leverage. According to Gangi et al. [9], the beneficial influence of CSR on banks' performance results primarily from the related improvement in reputation, which in turn creates a significant competitive advantage, allowing them to attract higher-skilled personnel and conduct operations in more favorable conditions than their competitors. Moreover, customers of more socially responsible banks might in fact be less price-sensitive, valuing banks' CSR engagement and reputation above purely economic benefits. This in turn would enable more responsible banks to realize higher margins and to allocate capital more efficiently, reducing the share of non-performing loans. On the other hand however, as pointed out by Oyewumi et al. [30], banks' investments in CSR are not likely to improve their financial performance without proper information disclosure.

As regards the value relevance literature, Miralles-Quiros et al. [40] examined the individual value relevance of environmental, social, and governance performance of banks listed on 20 different stock markets over the period 2002-2015 and reported that the equity investors valued each of these three ESG pillars in a different manner. Consistent with prior studies, they demonstrated that the value relevance of banks' ESG performance increased after the global financial crisis, and that it was generally higher in common law countries.

To date, only a few studies in the international literature have attempted to directly investigate the impact of CSR on the value relevance of financial data in the banking sector. Carnevale et al. [50] examined a sample composed of all 130 European-listed banks from the Euro-12 zone to assess the incremental value relevance of social reports announced over the period 2002-2008. Their findings suggest that such reports tend to be more common among banks with higher stock prices, book values per share and earnings per share. Additionally, banks publishing social reports exhibited, on average, a lower volatility of stock prices, which suggests that the information content of such reports might improve the efficiency of market valuation. The results of regression analysis for the pooled sample indicated, however, that the impact of social reporting on banks' market values as well as on the value relevance of their reported book values and earnings was statistically insignificant. By contrast, at the country level, they found some mixed evidence of the value relevance of social reports in the banking sector. In Germany, Italy, and Spain such reports seemed to exert a positive impact on banks' market values, while in Portugal, Austria, and France this influence appeared to be negative. These findings suggest, in turn, that the value relevance of CSR-related reporting might be largely dependent on the country-specific contextual factors.

In another study, based on a sample of 176 European listed banks over the period 2002-2011, Carnevale and Mazzuca [51] demonstrated that sustainability reports were generally value relevant and usually affected bank market values positively, although the cross-country analysis again revealed significant differences between particular markets. Furthermore, consistent with Carnevale et al. [50], they argued that social reporting did not influence the value relevance of net earnings; however, it seemed to decrease the informativeness of book values of equity. According to Carnevale and Mazzuca [51], the latter result reflects a partial complementarity between the information content of sustainability reports and financial statements with respect to the assessment of the impact of social and environmental risks that might reduce future earnings and in this way adversely affect the relevance of book values.

In a recent study, Arraiano [52] examined the value relevance of accounting data of 66 European banks listed in France, Germany, Italy, the Netherlands, Norway, Spain, and the United Kingdom over the period 2001-2013. Her findings indicate that inclusion in the Dow Jones Sustainability Index Europe (DJSIE) affected banks' market values both directly and indirectly by modifying the value relevance of their financial disclosures. Interestingly, however, in the period preceding the global financial crisis (2001-2007), inclusion in the index was generally associated with significantly higher valuation of banks' book values, whereas in 2008-2013 the above relationship reversed, which seems to corroborate the 
findings of Carnevale and Mazzuca [51]. The study also provides evidence of higher valuation of reported earnings in banks included in the DJSIE in the post-crisis period.

\subsubsection{The Evidence from Emerging and Post-Transition Economies}

The empirical evidence on the relationship between social and financial performance of banks from emerging markets is equally inconclusive. Many studies suggest that engagement in CSR-related activities does not exert a statistically significant impact on banks' financial performance or that such impact is negative. For instance, the results of an investigation of commercial banks in Bangladesh by Ahmed et al. [32] revealed that although ROA of more socially responsible banks seemed to be higher than that of their less responsible counterparts, the observed differences were not statistically significant. Similar results are reported for the Kenyan banking sector by Nyamute and Batta [33], who concluded that banks tended to engage in CSR-related activities mostly to build brand image and customer loyalty, rather than to achieve a substantial improvement of their financial performance. In a similar vein, Ofori et al. [39] demonstrated that although commercial banks operating in Ghana perceived social responsibility as a strategic tool able to improve their profitability, their actual financial performance seemed to be driven primarily by other factors, such as growth, leverage, and size.

The results of a study by Hafez [34] conducted on local, international, and Islamic banks operating in Egypt suggested that although CSR did not affect their ROA, it exhibited a weak positive relationship with ROE and net interest margin (NIM). Similar results are reported by Taşkin [35], who demonstrated that although CSR engagement did not affect ROA and ROE of Turkish banks, it enabled them to achieve significantly higher NIM. Socially responsible banks may therefore be able to charge higher fees and commissions than their market competitors. On the one hand, the above findings imply that customers preferring socially responsible behavior of banks may be willing to accept higher costs of products and services. On the other hand, however, the costs of CSR activities are likely to be transferred on to banks' customers, which means that they are borne not only by financial institutions themselves, but also by society. Moreover, Hamad et al. [36] demonstrated that total costs involved in CSR activities of commercial banks listed on the Iraq Stock Exchange exerted a negative impact on both ROA and return on investment (ROI). Interestingly, however, even though individual responsibility areas (employees, community, and customers) affected ROA adversely, their association with ROI appeared to be positive.

The empirical evidence on the relationship between CSR and bank financial performance in the Polish banking sector appears to be very limited. A direct investigation of the above issue has been performed by Matuszak and Różańska [38], who examined banks listed on the Warsaw Stock Exchange over the period 2008-2015 and reported that CSR activities did not exert a statistically significant impact on any of the key measures of their financial performance (ROA, ROE, or NIM). Similar results are reported also in a broader context by Fijałkowska et al. [37], who examined a sample of the 20 largest banks listed on the Central and Eastern European stock exchanges over the period 2012-2016 and found no evidence of a significant causal relationship between banks' social and financial performance in any direction. They did report, however, that better financially performing banks exhibited a better CSR performance, arguing that well managed banks are likely to perform well in both areas.

The results of studies on value relevance of banks' CSP in emerging markets are also largely mixed. Research in the Turkish banking sector by Aras et al. [41] reported an insignificant relationship between banks' sustainability efforts and market value. By contrast, Gitahi et al. [42] investigated the impact of CSR disclosures of banks listed on the Nairobi Securities Exchange in Kenya on the value relevance of their annual reports. Basing on the results of a survey conducted among financial analysts, they found a significant positive impact of CSR disclosure on the value relevance of banks' annual reports. Rahman et al. [43] demonstrated that although sustainability reports positively affected 
banks' market values in Bangladesh, earnings management practices tended to moderate the direction of this association negatively. In the same market setting, Rahman et al. [86] reported a significant positive influence of CSR disclosures on banks' stock prices. Moreover, their findings suggest that CSR disclosures by Islamic banks tended to be valued more positively than the ones by conventional commercial banks. In another study on Bangladeshi banks, Bose et al. [44] found that the level of CSR expenditure was generally positively related to their market values and that abnormal or unexpected components of such expenditure contained significant value relevant information. They also found the evidence of an inverse U-shaped relationship between the above variables, which means that beyond a certain limit, further increases in CSR expenditure are likely to destroy shareholder value.

It appears, therefore, that to date only a handful of studies in the international literature have attempted to directly explore the impact of banks' social performance on the value relevance of their financial disclosures, but apparently none of them has done it in the context of emerging or post-transition economies. Hence, the present paper attempts to fill this gap, using the data from the Polish banking sector.

\section{Materials and Methods}

The review of the relevant literature given in Section 2, and in particular the empirical evidence and arguments provided by $[46,47,49-51,55-57,85]$ and by [52] for the post-GFC period, allow us to formulate the following set of hypotheses:

H1: More socially responsible banks exhibit higher value relevance of financial data.

H2: Better CSP increases (decreases) the responsiveness of banks' market values to the changes in net earnings (book values of equity).

The investigation of both hypotheses has been based on multivariate linear regression analysis employing a simplified version of the Ohlson $[53,54]$ model, which appears to be one of the most frequently applied research frameworks in the contemporary market-based accounting research. Under it, the variation in market value of a given company can be explained by the variability of its key accounting items, i.e., book values of equity and net earnings, according to following formula, henceforth Equation (1):

$$
p_{i t}=\beta_{0}+\beta_{1} B V P S_{i t}+\beta_{2} E P S_{i t}+\varepsilon_{i t},
$$

where:

- $\quad p_{i t}$-the price of bank $i$ stock at the end of the year $t$,

- $\quad B V P S_{i t}$-book value per share of bank $i$ at the end of the year $t$,

- $E P S_{i t}$-net earnings per share of bank $i$ for the period $(t-1, t)$,

- $\beta_{0}$-intercept,

- $\beta_{1}, \beta_{2}$-regression coefficients,

- $\varepsilon_{i t}$-error term.

Following basic intuition and the prior evidence on the value relevance of accounting variables in the Polish banking sector, see, e.g. $[87,88]$, the estimates of both regression coefficients are expected to be positive.

The examined sample covers all domestic banks listed on the Warsaw Stock Exchange over the period 2009-2020, during which the listed companies were evaluated from the standpoint of their CSP so as to determine the sustainability leaders to be included in the established CSR indices. The first such index, the Respect Index, was launched by WSE in November 2009 and soon became the benchmark for the companies engaging in CSR activities and the point of reference for equity investors concerned with environmental, social, and governance aspects of the listed companies' operations. The index was designed to include socially responsible companies from the WSE Main List that operated in compliance with the best corporate governance, information governance, and investors relations standards and also in adherence to environmental, social, and personnel 
criteria [89]. After ten years of publication, in 2019 it was replaced by the WIG-ESG index, administrated by the WSE's subsidiary company, GPW Benchmark SA. WIG-ESG is a total return index covering the companies recognized as socially responsible, i.e., complying with the CSR principles, with a particular focus on environmental, social, economic, and corporate governance issues [90].

Inclusion in the CSR indices can therefore serve as a proxy for sustainability leadership and an indicator of a superior CSR performance of a given company in a given year. As the selection criteria involved a thorough evaluation of the quality of corporate reporting and communication with the market, following the findings of $[46,47,55-57]$, companies included in the indices could be expected to provide equity investors with more reliable, transparent, and value-relevant financial reports. They were also more likely to disclose additional value relevant information in the form of comprehensive sustainability reports or high-quality statements on non-financial information.

After taking into account the mergers and acquisitions in the industry, the final sample comprised 17 banks. The accounting data from banks' separate annual financial reports have been extracted from the Notoria Serwis [91], whereas the data on stock prices have been collected via the website of the Brokerage House of Bank Ochrony Środowiska SA [92]. The combined data on stock prices, outstanding shares, book values of equity, and net earnings yielded the final pooled sample of 154 bank-year observations.

The sample has been divided into two subsamples depending on the CSP of each bank in a given year. The first subsample (henceforth Responsible) has covered the banks included in at least one of the CSR indices published by WSE, i.e., the Respect Index or WIG-ESG and, as such, deemed to be more socially responsible and thus more likely to produce high quality reports covering a broad spectrum of value relevant information. In fact, for almost $74 \%$ of bank-year observations in the subsample (i.e., 51 out of 69 cases) the examined banks prepared separate sustainability reports, whereas for the next $23 \%$ of cases (16), their CSR and ESG-related disclosures took the form of comprehensive statements on non-financial information within the reports of the management boards. The second subsample (henceforth Other) comprised the remainder of the examined banks.

The key statistics for the pooled sample and the investigated subsamples of banks are reported in Table 1.

Table 1. Summary statistics.

\begin{tabular}{lccccccc}
\hline Sample & Variable & Mean & Median & Min & Max & SD & N \\
\hline \multirow{5}{*}{ Pooled } & P [PLN] & 108.96 & 59.40 & 0.23 & 894.00 & 140.88 & \\
& BVPS [PLN] & 75.15 & 53.21 & 0.22 & 417.99 & 85.20 & 154 \\
& EPS [PLN] & 6.03 & 3.12 & -20.82 & 53.98 & 9.38 & \\
\hline \multirow{5}{*}{ Responsible } & P [PLN] & 139.12 & 81.88 & 3.27 & 894.00 & 169.48 & \\
& BVPS [PLN\} & 98.18 & 56.21 & 2.96 & 417.99 & 104.14 & 69 \\
& EPS [PLN] & 8.28 & 5.00 & -3.97 & 53.98 & 10.61 & \\
\hline \multirow{5}{*}{ Other } & P [PLN] & 84.48 & 46.09 & 0.23 & 500.00 & 107.45 & \\
& BVPS [PLN] & 56.45 & 45.65 & 0.22 & 308.04 & 60.43 & 85 \\
& EPS [PLN] & 4.20 & 2.61 & -20.82 & 30.10 & 7.85 & \\
\hline
\end{tabular}

In the first step of the research, Equation (1) has been estimated for the pooled sample and each of the subsamples, aiming at the assessment and comparison of its overall descriptive power (as measured with the coefficient of determination) and the individual regression parameters in each estimation. The presence of heteroskedasticity has been verified with the Breusch-Pagan/Cook-Weisberg test. Given the use of panel data, the model has also been tested for the presence of random and fixed effects using the BreuschPagan Lagrangian multiplier test and $F$-test, respectively.

Next, the overall significance of the differences between the regression coefficients estimated for each subsample has been assessed with the Chow test for structural breaks [93] (pp. 255-259). 
Finally, to evaluate the statistical significance of the impact of CSR performance on the relative responsiveness of banks' market values to the changes in book values and net earnings, the model has been extended by the introduction of a dummy variable differentiating between the Responsible and Other banks, yielding the following formula, henceforth Equation (2):

$$
p_{i t}=\beta_{0}+\beta_{0 \mathrm{D}} D_{i}+\beta_{1} B V P S_{i t}+\beta_{2} E P S_{i t}+\beta_{3}\left(D_{i} B V P S_{i t}\right)+\beta_{4}\left(D_{i} E P S_{i t}\right)+\varepsilon_{i t},
$$

where:

- $\quad D_{i}$-a dummy variable equal 1 for the banks included in Respect Index or WIG-ESG and 0 for the others.

As regards the estimate of the coefficient $\beta_{3}$, the mixed evidence in the relevant literature does not allow us to formulate an unequivocal prediction about its sign. On the one hand, more socially responsible banks should provide the equity investors with higherquality financial data, which implies a stronger positive relationship between book and market values (as demonstrated by [48] and in the pre-GFC period by [52]), but on the other, several studies report a statistically insignificant or even negative impact of CSP on the responsiveness of market values to changes in book values of equity, see, e.g., [46,47,50-52]. In the present study, however, following [47,51,52], the estimate of the coefficient $\beta_{3}$ is hypothesized to be negative. In turn, as suggested by [45-49,52,55-57], the estimate of the coefficient $\beta_{4}$ is expected to be positive, since a better CSP should generally correspond to higher informativeness of earnings.

\section{Results}

The results of the estimations of Equation (1) for the pooled sample (Panel A) and the examined subsamples of banks (Panels B and C) are given in Table 2. Due to heteroskedasticity indicated by the Breusch-Pagan/Cook-Weisberg test, all regressions have been estimated using robust standard errors. Moreover, as the results of the Breusch-Pagan Lagrangian multiplier test and F-test suggest that both random and fixed effects in the examined sample are statistically insignificant, the estimates have been obtained using pooled OLS.

The results presented in Table 2 indicate that each of the estimated regressions is statistically significant and fits the empirical data well. Except for the coefficient $\beta_{2}$ in the regression for Other banks, all estimated regression coefficients are statistically significant at the 0.01 level.

The comparison between the estimates obtained for each of the subsamples reveals evident differences in the relative value relevance of the employed explanatory variables. First, a pronounced difference of nearly 15 percentage points in the estimates of the coefficients of determination between the subsamples strongly suggests that an overall ability of the examined accounting items to explain the variance in banks' market values is markedly higher in the case of more socially responsible banks, thus supporting the first hypothesis of the present study. Second, while the market values of more responsible banks seem to be much more sensitive to the changes in net earnings than those of Other banks, in the case of their relative responsiveness to the changes in book values of equity, the situation is exactly opposite. These findings, in turn, are largely consistent with the prior empirical evidence in the relevant literature and provide some initial support for the second hypothesis of the study. 
Table 2. Estimations of Equation (1).

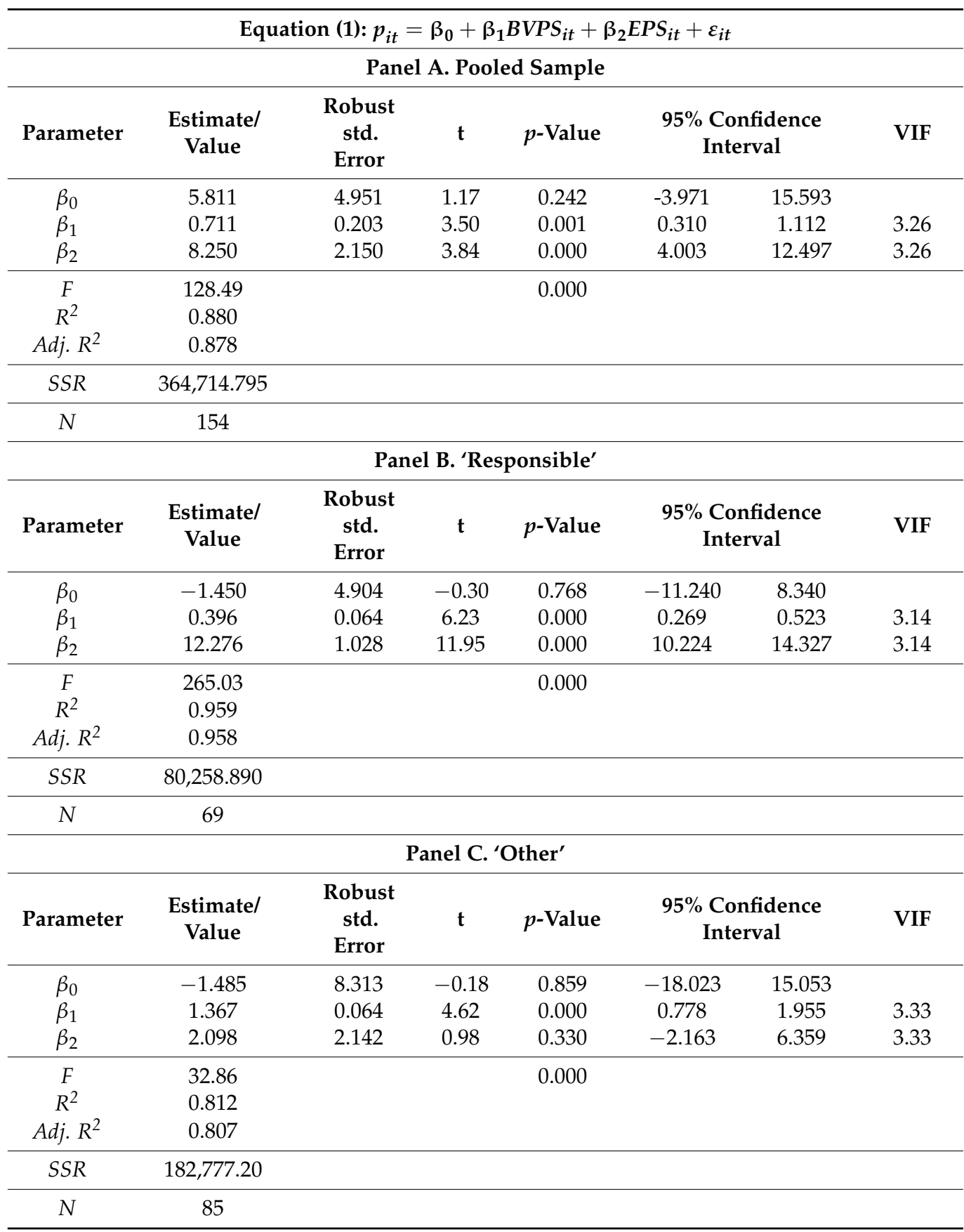

In order to determine whether the banks included in the CSR indices of WSE differ systematically from their less socially responsible counterparts in terms of the sensitivity of market values to the changes in the examined accounting variables, the Chow test has been employed. The estimate of the test statistic equals 19.070 and exceeds the corresponding critical value of the F-distribution at the 0.01 level (3.917), indicating a statistically significant structural break in the regression parameters of Equation (1) between the examined subsampled of banks.

The final stage of the research has involved the estimation of Equation (2) aimed at assessment of the statistical significance of the impact of the CSR performance on the responsiveness of banks' market values to the changes in each of the examined accounting variables (Table 3). 
Table 3. Estimations of Equation (2).

\begin{tabular}{|c|c|c|c|c|c|c|c|}
\hline \multicolumn{8}{|c|}{ Equation (2): $p_{i t}=\beta_{0}+\beta_{0 \mathrm{D}} D_{i}+\beta_{1} B V P S_{i t}+\beta_{2} E P S_{i t}+\beta_{3}\left(D_{i} B V P S_{i t}\right)+\beta_{4}\left(D_{i} E P S_{i t}\right)+\varepsilon_{i t}$} \\
\hline \multicolumn{8}{|c|}{ Pooled Sample } \\
\hline \multirow{2}{*}{$\begin{array}{c}\text { Parameter } \\
\qquad \beta_{0}\end{array}$} & \multirow{2}{*}{$\begin{array}{c}\begin{array}{c}\text { Estimate/ } \\
\text { Value }\end{array} \\
-1.485\end{array}$} & \multirow{2}{*}{$\begin{array}{c}\begin{array}{c}\text { Robust } \\
\text { std. } \\
\text { Error }\end{array} \\
8.329\end{array}$} & \multirow{2}{*}{$\begin{array}{c}\mathbf{t} \\
-0.18\end{array}$} & \multirow{2}{*}{$\begin{array}{c}p \text {-Value } \\
0.859\end{array}$} & \multicolumn{2}{|c|}{$\begin{array}{l}\text { 95\% Confidence } \\
\text { Interval }\end{array}$} & VIF \\
\hline & & & & & -17.944 & 14.974 & \\
\hline$\beta_{0 \mathrm{D}}$ & 0.035 & 9.659 & 0.00 & 0.997 & -19.053 & 19.123 & 1.99 \\
\hline$\beta_{1}$ & 1.367 & 0.296 & 4.61 & 0.000 & 0.781 & 1.952 & 12.07 \\
\hline$\beta_{2}$ & 2.098 & 2.146 & 0.98 & 0.330 & -2.142 & 6.339 & 8.68 \\
\hline$\beta_{3}$ & -0.971 & 0.303 & -3.20 & 0.002 & -1.570 & -0.372 & 16.70 \\
\hline$\beta_{4}$ & 10.177 & 2.378 & 4.28 & 0.000 & 5.478 & 14.877 & 10.83 \\
\hline$F$ & 126.27 & & & 0.000 & & & \\
\hline$R^{2}$ & 0.913 & & & & & & \\
\hline Adj. $R^{2}$ & 0.911 & & & & & & \\
\hline$S S R$ & $263,036.09$ & & & & & & \\
\hline$N$ & 154 & & & & & & \\
\hline
\end{tabular}

The obtained estimates of the coefficients $\beta_{3}$ and $\beta_{4}$ are statistically significant at all conventional levels. Consistent with the ex ante expectations, a negative estimate of coefficient $\beta_{3}$ suggests that a better CSP is associated with a lower responsiveness of banks' market values to changes in book values of equity. In turn, the coefficient $\beta_{4}$ is significantly positive, which indicates that more socially responsible banks exhibit higher sensitivity of market value to changes in net earnings. Hence, the above results provide additional support for the second hypothesis of the present study.

\section{Discussion}

The results of the study support the hypothesized view that the value relevance of key financial data is higher in more socially responsible banks. Generally, consistent with the results of previous investigations in the Polish banking sector $[87,88]$, increases in both book values of equity and net earnings positively affected the market values of listed banks. However, the joint ability of these accounting items to explain the variation in the market values of the banks listed on WSE has turned out to be markedly higher in the case of the subsample composed of banks included the CSR indices of WSE, i.e., Respect Index and WIGESG. These findings not only corroborate the results of prior studies, see e.g., [45-49,52,55-57], but also provide additional arguments supporting the view that successful implementation of CSR principles in practice may play an important role in reduction of informational asymmetry between management and equity investors, especially in the case of complex and opaque business models, such as those of banks [12]. In this way, the obtained results strongly justify the need for further development and extension of both depth and width of international legal regulations and policy initiatives promoting socially responsible business behavior and its reporting, such as the European Parliament and Council Directive 2014/95/EU [94] or the European Green Deal [95].

Moreover, the findings of the present study indicate that a better CSP appears to exert a different impact on the relative sensitivity of banks' market values to the changes in each of the examined accounting variables. Consistent with $[46-49,52,55-57,85]$ on the one hand, but contrary to $[50,51]$ on the other, the market values of banks included in the CSR indices of WSE appeared to be significantly more sensitive to variation in net earnings in comparison to their less socially responsible counterparts. Additionally, only in the case of more socially responsible banks did the earnings response coefficient turn out to be statistically significant. These results may be viewed as an evidence of a higher quality and informativeness of earnings reported by more socially responsible banks. Following [55-57], this effect might be attributable to the fact that more responsible banks are less likely to 
engage in earnings management practices, which results in higher informativeness of their earnings disclosures. It is also plausible that, as in the case of other industries, equity investors in the banking sector may perceive the reputation for being committed to sustainability as an intangible asset able to increase the value and/or reduce the volatility of expected cash flows, as pointed out by [46]. Furthermore, sustainability leadership might be perceived by equity investors as a path towards mitigation of regulatory risks and additional profits from responsible business activities, which in turn, can boost the market valuation of banks' earnings, as argued by [85].

Simultaneously, in line with [47,51] and partially also with [52], in the case of banks listed on the WSE, better CSP seemed to diminish the responsiveness of their market values to changes in book values of equity. On the one hand, given the fact that book value of equity often serves as a proxy for a firm's liquidation or abandonment value [96], it is likely that investors perceive more socially responsible banks as more resilient and viable, which allows them to assign lower importance to this accounting variable. On the other hand, however, it is also plausible that the above effect results from additional disclosures regarding the banks' risk exposure, which might be partly complementary with the information content of book values, as suggested by [51].

The fact that CSP seems to moderate the informativeness of individual accounting items in different ways provides yet another argument for the significance of the findings of the present study for the design of integrated reporting standards both in the banking sector and in other industries. Future evolution of international regulations regarding financial and non-financial corporate disclosures, including in particular the European Commission Regulation (EC) No. 1126/2008 adopting certain international accounting standards [97] and the aforementioned Directive 2014/95/EU [94], should therefore take into account the apparent complementarities and feedbacks existing between these two categories of information, so as to ensure maximum efficiency and value relevance of reporting efforts.

Overall, the above findings are largely consistent with the evidence in the relevant literature and seem to support each of the formulated hypotheses. The main limitations of the present study arise from the fact that its conclusions are based on the data from a single stock market over a particular period; therefore, given the mixed results of prior cross-country [50] and cross-time [52] investigations, they should not be mechanically extended to other contexts. Moreover, the research has investigated the impact of CSR performance on the value relevance of only two key accounting variables, i.e., book values of equity and net earnings, although it is highly likely that analogous effects might be present in the case of other financial disclosures.

\section{Conclusions}

The present study aimed at empirical investigation of the impact of corporate social performance on the value relevance of key accounting items (i.e., book values of equity and net earnings) in the specific context of the Polish banking sector. The results of a multivariate regression analysis based on the Ohlson model applied to the sample of all domestic banks listed on the Warsaw Stock Exchange over the period 2009-2020 demonstrate that banks included in the CSR indices of the WSE exhibited markedly higher value relevance of key financial data than their less socially responsible counterparts. Additionally, largely consistent with the results of prior studies, the findings of the research suggest that commitment to sustainability affects the responsiveness of banks' market values to changes in book values of equity and net earnings differently. On the one hand, better CSP improves the informativeness of earnings, strengthening their positive impact on banks' market values. On the other hand, however, it seems to weaken the responsiveness of market values to changes in book values of equity. These findings support the view that more socially responsible banks appear to be less prone to manage earnings, which generally improves their quality. In turn, a lower sensitivity of market values to fluctuations in book values likely reflects the complementarities between banks' CSR and financial 
disclosures and/or the fact that equity investors may perceive socially responsible banks as more resilient and viable.

The main contributions of the present paper are threefold.

First, the study enhances the existing international literature by providing direct empirical evidence on the impact of CSR performance on the value relevance of financial data in the Polish banking sector. To the best of the author's knowledge, to date the above issue has not been explored in the context of any other post-transition or emerging economy.

Second, the results of the research suggest that following the path of social responsibility may enable banks to reduce the inevitable informational asymmetry existing between them and the market. In this way the paper contributes to the general discussion on the practical usefulness of CSR by providing some additional arguments supporting the need for the further development of legal regulations promoting social responsibility and its reporting.

Third, given the identified moderating impact of banks' CSR performance on the informativeness of their financial disclosures, the present paper contributes to the strand of literature exploring the linkages, complementarities, and feedbacks between the financial and non-financial information disclosures. The findings of the study may therefore prove useful for the further development of the integrated reporting standards in the banking sector and improvement of their informativeness and efficiency from the standpoint of equity investors.

The importance of in-depth exploration of the linkages between CSP and the value relevance of accounting variables in the banking sector, for the development of both the discipline of finance and reporting standards in the banking sector, provides a strong argument for continuation of the international research efforts in that field. Given the limitations of the present study highlighted in Section 5, future investigations might attempt to evaluate the impact of bank CSR performance on the value relevance of financial disclosures in other emerging and post-transitional economies, preferably examining broader sets of accounting variables. Further research efforts are also needed to determine the exact range of complementarities between financial and non-financial disclosures, as well as to assess the impact of various bank-specific variables (e.g., size or capital adequacy) on the identified relationships.

Funding: The APC was funded by the John Paul II Catholic University of Lublin, internal grant no. 05-0501-2-0592.

Institutional Review Board Statement: Not applicable.

Informed Consent Statement: Not applicable.

Data Availability Statement: Data supporting reported results can be found at: https://www.emis. com/pl; https:/ /info.bossa.pl/pub/metastock/mstock/ (accessed on 10 June 2021), https:/ / www. world-exchanges.org/storage/app/media/WFE\%20Annual\%20Statitics\%20Guide\%202020\%20v15. xlsx, and https:/ / www.gpw.pl/gpw-key-statistics (accessed on 14 June 2021).

Acknowledgments: The author would like to thank the anonymous reviewers for their insightful comments and suggestions that helped to improve the present paper.

Conflicts of Interest: The author declares no conflict of interest. The funders had no role in the design of the study; in the collection, analyses, or interpretation of data; in the writing of the manuscript, or in the decision to publish the results.

\section{References}

1. Carroll, A.B. Corporate Social Responsibility (CSR) and Corporate Social Performance (CSP). In The SAGE Encyclopedia of Business Ethics and Society; Kolb, R.W., Ed.; SAGE Publications, Inc.: Thousand Oaks, CA, USA, 2018; pp. 746-754.

2. Aguinis, H.; Glavas, A. What We Know and Don't Know About Corporate Social Responsibility: A Review and Research Agenda. J. Manag. 2012, 38, 932-968. [CrossRef]

3. Aguilera, R.V.; Rupp, D.E.; Williams, C.A.; Ganapathi, J. Putting the S Back in Corporate Social Responsibility: A Multilevel Theory of Social Change in Organizations. Acad. Manag. Rev. 2007, 32, 836-863. [CrossRef] 
4. Thompson, P.; Cowton, C.J. Bringing the Environment into Bank Lending: Implications for Environmental Reporting. Br. Account. Rev. 2004, 36, 197-218. [CrossRef]

5. Zioło, M. Business Models of Banks Toward Sustainability and ESG Risk. In Sustainability in Bank and Corporate Business Models. The Link between ESG Risk Assessment and Corporate Sustinability; Palgrave Macmillan: London, UK, 2021; pp. $185-209$.

6. Koleśnik, J. Operational Risk in Banks-Revolution or Regulatory Evolution. Res. Pap. Wroc. Univ. Econ. 2018, 168-178. [CrossRef]

7. Lentner, C.; Szegedi, K.; Tatay, T. Corporate Social Responsibility in the Banking Sector. Public Financ. Q. 2015, 60, 95-103.

8. Branco, M.C.; Rodrigues, L.L. Social Responsibility Disclosure: A Study of Proxies for the Public Visibility of Portuguese Banks. Br. Account. Rev. 2008, 40,161-181. [CrossRef]

9. Gangi, F.; Mustilli, M.; Varrone, N.; Daniele, L. Corporate Social Responsibility and Banks' Financial Performance. Int. Bus. Res. 2018, 11, 42-58. [CrossRef]

10. 2021 Edelman Trust Barometer. Available online: https:/ / www.edelman.com/trust/2021-trust-barometer (accessed on 11 June 2021).

11. Djalilov, K.; Vasylieva, T.; Lyeonov, S.; Lasukova, A. Corporate Social Responsibility and Bank Performance in Transition Countries. Corp. Ownersh. Control 2015, 13, 879-888. [CrossRef]

12. Koller, T.; Goedhart, M.; Wessels, D. Valuation: Measuring and Managing the Value of Companies, 7th ed.; Wiley: Hoboken, NJ, USA, 2020; ISBN 978-1-119-61088-5.

13. Healy, P.M.; Palepu, K.G. Information Asymmetry, Corporate Disclosure, and the Capital Markets: A Review of the Empirical Disclosure Literature. J. Account. Econ. 2001, 31, 405-440. [CrossRef]

14. Viganò, F.; Nicolai, D. CSR in the European Banking Sector: Evidence from a Survey. In Corporate Social Responsibility in Europe. Rhetoric and Realities; Barth, R., Wolff, F., Eds.; Edward Elgar Publishing: Cheltenham, UK, 2009; pp. 95-108; ISBN 978-1-84720-764-7.

15. Fijałkowska, J.; Zyznarska-Dworczak, B. Sustainability Reporting of Polish Banks-A Step towards Greater Accountability? Entrep. Manag. 2018, 39, 47-61.

16. Krasodomska, J. CSR Disclosures in the Banking Industry. Empirical Evidence from Poland. Soc. Responsib. J. 2015, 11, 406-423. [CrossRef]

17. Lundgren, T. On the Economics of Corporate Social Responsibility; Swedish University of Agricultural Sciences: Umeå, Sweden, 2007.

18. Barnett, M.L. Stakeholder Influence Capacity and the Variability of Financial Returns to Corporate Social Responsibility. Acad. Manag. Rev. 2007, 32, 794-816. [CrossRef]

19. Gompers, P.; Ishii, J.; Metrick, A. Corporate Governance and Equity Prices. Q. J. Econ. 2003, 118, 107-156. [CrossRef]

20. Mahoney, L.; Roberts, R.W. Corporate Social Performance, Financial Performance and Institutional Ownership in Canadian Firms. Account. Forum 2007, 31, 233-253. [CrossRef]

21. Wright, P.; Ferris, S.P. Agency Conflict and Corporate Strategy: The Effect of Divestment on Corporate Value. Strateg. Manag. J. 1997, 18, 77-83. [CrossRef]

22. Bauer, R.; Guenster, N.; Otten, R. Empirical Evidence on Corporate Governance in Europe: The Effect on Stock Returns, Firm Value and Performance. J. Asset Manag. 2004, 5, 91-104. [CrossRef]

23. Margolis, J.D.; Walsh, J.P. Misery Loves Companies: Rethinking Social Initiatives by Business. Adm. Sci. Q. 2003, 48, 268-305. [CrossRef]

24. Orlitzky, M.; Schmidt, F.L.; Rynes, S.L. Corporate Social and Financial Performance: A Meta-Analysis. Organ. Stud. 2003, 24, 403-441. [CrossRef]

25. Knight, H.H.; Ellson, T. Value Drivers of Corporate Social Responsibility: The Role of Explicit Value and Back Value. Soc. Bus. 2017, 7, 27-47. [CrossRef]

26. Simpson, W.G.; Kohers, T. The Link between Corporate Social and Financial Performance: Evidence from the Banking Industry. J. Bus. Ethics 2002, 35, 97-109. [CrossRef]

27. Cheung, P.; Mak, W. The Relation between Corporate Social Responsibility Disclosure and Financial Performance: Evidence from the Commercial Banking Industry. Master's Thesis, Simon Fraser University, Burnaby, BC, Canada, August 2010.

28. Soana, M.-G. The Relationship between Corporate Social Performance and Corporate Financial Performance in the Banking Sector. J. Bus. Ethics 2011, 104, 133. [CrossRef]

29. Chih, H.-L.; Chih, H.-H.; Chen, T.-Y. On the Determinants of Corporate Social Responsibility: International Evidence on the Financial Industry. J. Bus. Ethics 2010, 93, 115-135. [CrossRef]

30. Oyewumi, O.R.; Ogunmeru, O.A.; Oboh, C.S. Investment in Corporate Social Responsibility, Disclosure Practices, and Financial Performance of Banks in Nigeria. Future Bus. J. 2018, 4, 195-205. [CrossRef]

31. Wu, M.-W.; Shen, C.-H. Corporate Social Responsibility in the Banking Industry: Motives and Financial Performance. J. Bank. Financ. 2013, 37, 3529-3547. [CrossRef]

32. Ahmed, S.U.; Islam, Z.M.; Hasan, I. Corporate Social Responsibility and Financial Performance Linkage: Evidence from the Banking Sector of Bangladesh. J. Organ. Manag. 2012, 1, 14-21.

33. Nyamute, W.; Batta, N. Effect of Corporate Social Responsibility on Financial Performance in the Banking Sector: Evidence from the Nairobi Securities Exchange. Asian Acad. Res. J. Soc. Sci. Humanit. 2014, 1. Available online: http://hdl.handle.net/11295/88 262 (accessed on 24 June 2021).

34. Hafez, H.M. Corporate Social Responsibility and Financial Performance: An Empirical Study on Egyptian Banks. Corp. Ownersh. Control 2015, 12, 102-127. [CrossRef]

35. Taskin, D. The Relationship between CSR and Banks' Financial Performance: Evidence from Turkey. Yaşar Üniversitesi E-Derg. 2015, 10, 21-30. [CrossRef] 
36. Hamad, M.K.; Jealo, K.A.; Ahmed, W.H. Impact of Corporate Social Responsibility on Financial Performance Applied Research in Iraqi Commercial Banks. Int. J. Innov. 2020, 12, 599-619.

37. Fijałkowska, J.; Zyznarska-Dworczak, B.; Garsztka, P. Corporate Social-Environmental Performance versus Financial Performance of Banks in Central and Eastern European Countries. Sustainability 2018, 10, 772. [CrossRef]

38. Matuszak, Ł.; Różańska, E. An Examination of the Relationship between CSR Disclosure and Financial Performance: The Case of Polish Banks. J. Account. Manag. Inf. Syst. 2017, 16, 522-533. [CrossRef]

39. Ofori, D.F.; Nyuur, R.B.; S-Darko, M.D. Corporate Social Responsibility and Financial Performance: Fact or Fiction? A Look at Ghanaian Banks. Acta Commer. 2014, 14, 180. [CrossRef]

40. Miralles-Quirós, M.d.M.; Miralles-Quirós, J.L.; Redondo-Hernández, J. The Impact of Environmental, Social, and Governance Performance on Stock Prices: Evidence from the Banking Industry. Corp. Soc. Responsib. Environ. Manag. 2019, 26, 1446-1456. [CrossRef]

41. Aras, G.; Tezcan, N.; Furtuna, O.K. The Value Relevance of Banking Sector Multidimensional Corporate Sustainability Performance. Corp. Soc. Responsib. Environ. Manag. 2018, 25, 1062-1073. [CrossRef]

42. Gitahi, J.; Nasieku, T.; Memba, F. Corporate Social Responsibility Disclosure and the Value Relevance of Annual Reports for Listed Banks in Kenya. Eur. Sci. J. ESJ 2018, 14, 329. [CrossRef]

43. Rahman, M.; Rasid, S.Z.A.; Basiruddin, R. Moderating Effect of Earnings Management in the Relationship between Sustainability Reporting Initiatives and Value Relevance. Indones. J. Sustain. Account. Manag. 2020, 4, 266-277. [CrossRef]

44. Bose, S.; Saha, A.; Abeysekera, I. The Value Relevance of Corporate Social Responsibility Expenditure: Evidence from Regulatory Decisions. Abacus 2020, 56, 455-494. [CrossRef]

45. Cormier, D.; Magnan, M. The Revisited Contribution of Environmental Reporting to Investors' Valuation of a Firm's Earnings: An International Perspective. Ecol. Econ. 2007, 62, 613-626. [CrossRef]

46. Lourenço, I.C.; Callen, J.L.; Branco, M.C.; Curto, J.D. The Value Relevance of Reputation for Sustainability Leadership. J. Bus. Ethics 2014, 119, 17-28. [CrossRef]

47. Sutopo, B.; Kot, S.; Adiati, A.K.; Ardila, L.N. Sustainability Reporting and Value Relevance of Financial Statements. Sustainability 2018, 10, 678. [CrossRef]

48. Reverte, C. Corporate Social Responsibility Disclosure and Market Valuation: Evidence from Spanish Listed Firms. Rev. Manag. Sci. 2016, 10, 411-435. [CrossRef]

49. Dimitropoulos, P.; Koronios, K. Corporate Environmental Responsibility and Earnings Value Relevance. In Corporate Environmental Responsibility, Accounting and Corporate Finance in the EU: A Quantitative Analysis Approach; Dimitropoulos, P., Koronios, K., Eds.; CSR: Cham, Switzerland, 2021; pp. 197-213. ISBN 978-3-030-72773-4.

50. Carnevale, C.; Mazzuca, M.; Venturini, S. Corporate Social Reporting in European Banks: The Effects on a Firm's Market Value. Corp. Soc. Responsib. Environ. Manag. 2012, 19, 159-177. [CrossRef]

51. Carnevale, C.; Mazzuca, M. Sustainability Report and Bank Valuation: Evidence from European Stock Markets. Bus. Ethics Eur. Rev. 2014, 23, 69-90. [CrossRef]

52. Arraiano, I.G. Is There Value Creation in the Banks Listed in the Dow Jones Sustainability Index Europe? In Responsible Business in a Changing World. New Management Approaches for Sustainable Development; Diaz, B.D., Capaldi, N., Idowu, S.O., Schmidpeter, R., Eds.; Springer: Cham, Switzerland, 2020; pp. 53-68.

53. Ohlson, J.A. Earnings, Book Values, and Dividends in Equity Valuation. Contemp. Account. Res. 1995, 11, 661-687. [CrossRef]

54. Ohlson, J.A. Earnings, Book Values, and Dividends in Equity Valuation: An Empirical Perspective. Contemp. Account. Res. 2001, 18, 107-120. [CrossRef]

55. Kim, Y.; Park, M.S.; Wier, B. Is Earnings Quality Associated with Corporate Social Responsibility? Account. Rev. 2012, 87, 761-796. [CrossRef]

56. Choi, T.H.; Pae, J. Business Ethics and Financial Reporting Quality: Evidence from Korea. J. Bus. Ethics 2011, 103, 403-427. [CrossRef]

57. Hsu, F.-J.; Chen, S.-H. Does Corporate Social Responsibility Drive Better Performance by Adopting IFRS? Evidence from Emerging Market. J. Comput. Appl. Math. 2020, 371, 112631. [CrossRef]

58. Bird, R.; Hall, A.D.; Momentè, F.; Reggiani, F. What Corporate Social Responsibility Activities Are Valued by the Market? J. Bus. Ethics 2007, 76, 189-206. [CrossRef]

59. Hockerts, K.; Moir, L. Communicating Corporate Responsibility to Investors: The Changing Role of the Investor Relations Function. J. Bus. Ethics 2004, 52, 85-98. [CrossRef]

60. McWilliams, A.; Siegel, D.S.; Wright, P.M. Corporate Social Responsibility: Strategic Implications. J. Manag. Stud. 2006, 43, 1-18. [CrossRef]

61. Siegel, D.S. Green Management Matters Only If It Yieds More Green: An Economic/Strategic Perspective. Acad. Manag. Perspect. 2009, 23, 5-16. [CrossRef]

62. KPMG The Time Has Come-The KPMG Survey of Sustainability Reporting 2020. Available online: https://home.kpmg/xx/en/ home/insights/2020/11/the-time-has-come-survey-of-sustainability-reporting.html (accessed on 9 June 2021).

63. Bowerman, S.; Sharma, U.P. The Effect of Corporate Social Responsibility Disclosures on Share Prices in Japan and the UK. Corp. Ownersh. Control 2016, 13, 202-216. [CrossRef]

64. Searcy, C.; Elkhawas, D. Corporate Sustainability Ratings: An Investigation into How Corporations Use the Dow Jones Sustainability Index. J. Clean. Prod. 2012, 35, 79-92. [CrossRef] 
65. Robinson, M.; Kleffner, A.; Bertels, S. Signaling Sustainability Leadership: Empirical Evidence of the Value of DJSI Membership. J. Bus. Ethics 2011, 101, 493-505. [CrossRef]

66. Murray, A.; Sinclair, D.; Power, D.; Gray, R. Do Financial Markets Care about Social and Environmental Disclosure? Further Evidence and Exploration from the UK. Account. Audit. Account. J. 2006, 19, 228-255. [CrossRef]

67. Jones, S.; Frost, G.; Loftus, J.; Laan, S.V.D. An Empirical Examination of the Market Returns and Financial Performance of Entities Engaged in Sustainability Reporting. Aust. Account. Rev. 2007, 17, 78-87. [CrossRef]

68. De Klerk, M.; de Villiers, C. The Value Relevance of Corporate Responsibility Reporting: South African Evidence. Meditari Account. Res. 2012, 20, 21-38. [CrossRef]

69. De Klerk, M.; de Villiers, C.; van Staden, C. The Influence of Corporate Social Responsibility Disclosure on Share Prices: Evidence from the United Kingdom. Pac. Account. Rev. 2015, 27, 208-228. [CrossRef]

70. Schadewitz, H.; Niskala, M. Communication via Responsibility Reporting and Its Effect on Firm Value in Finland. Corp. Soc. Responsib. Environ. Manag. 2010, 17, 96-106. [CrossRef]

71. Lourenço, I.C.; Branco, M.C.; Curto, J.D.; Eugénio, T. How Does the Market Value Corporate Sustainability Performance? J. Bus Ethics 2012, 108, 417-428. [CrossRef]

72. Berthelot, S.; Coulmont, M.; Serret, V. Do Investors Value Sustainability Reports? A Canadian Study. Corp. Soc. Responsib. Environ. Manag. 2012, 19, 355-363. [CrossRef]

73. Cardamone, P.; Carnevale, C.; Giunta, F. The Value Relevance of Social Reporting: Evidence from Listed Italian Companies. J. Appl. Account. Res. 2012, 13, 255-269. [CrossRef]

74. Miralles-Quiros, M.d.M.; Miralles-Quiros, J.L.; Arraiano, I.G. Are Firms That Contribute to Sustainable Development Valued by Investors? Corp. Soc. Responsib. Environ. Manag. 2017, 24, 71-84. [CrossRef]

75. Cheng, B.; Ioannou, I.; Serafeim, G. Corporate Social Responsibility and Access to Finance. Strateg. Manag. J. 2014, 35, 1-23. [CrossRef]

76. Dhaliwal, D.S.; Li, O.Z.; Tsang, A.; Yang, Y.G. Voluntary Nonfinancial Disclosure and the Cost of Equity Capital: The Initiation of Corporate Social Responsibility Reporting. Account. Rev. 2011, 86, 59-100. [CrossRef]

77. Gregory, A.; Tharyan, R.; Whittaker, J. Corporate Social Responsibility and Firm Value: Disaggregating the Effects on Cash Flow, Risk and Growth. J. Bus. Ethics 2014, 124, 633-657. [CrossRef]

78. Ioannou, I.; Serafeim, G. The Impact of Corporate Social Responsibility on Investment Recommendations: Analysts' Perceptions and Shifting Institutional Logics. Strateg. Manag. J. 2015, 36, 1053-1081. [CrossRef]

79. Lee, C.; Palmon, D.; Yezegel, A. The Corporate Social Responsibility Information Environment: Examining the Value of Financial Analysts' Recommendations. J. Bus. Ethics 2018, 150, 279-301. [CrossRef]

80. Cabral, L. Living Up to Expectations: Corporate Reputation and Persistence of Firm Performance. Strategy Sci. 2016, 1, 2-11. [CrossRef]

81. Flammer, C. Corporate Social Responsibility and Shareholder Reaction: The Environmental Awareness of Investors. Acad. Manag. J. 2013, 56, 758-781. [CrossRef]

82. Jo, H.; Harjoto, M.A. The Causal Effect of Corporate Governance on Corporate Social Responsibility. J. Bus. Ethics 2012, 106, 53-72. [CrossRef]

83. Kaspereit, T.; Lopatta, K. The Value Relevance of SAM's Corporate Sustainability Ranking and GRI Sustainability Reporting in the European Stock Markets. Bus. Ethics Eur. Rev. 2016, 25, 1-24. [CrossRef]

84. Miralles-Quiros, M.d.M.; Miralles-Quiros, J.L.; Arraiano, I.G. Sustainable Development, Sustainability Leadership and Firm Valuation: Differences across Europe. Bus. Strategy Environ. 2017, 26, 1014-1028. [CrossRef]

85. Bailey, J.; Koller, T. Sustainability and Rewriting the Book on Valuation: An Interview with Tim Koller. J. Appl. Corp. Finance 2017, 29, 16-20. [CrossRef]

86. Rahman, M.; Abdul Rasid, S.Z.; Basiruddin, R. Corporate Social Responsibility Reporting and Value Relevance of the Banking Sector in Bangladesh. J. Sustain. Sci. Manag. 2020, 15, 192-214. [CrossRef]

87. Bolibok, P. The Impact of IFRS on the Value Relevance of Accounting Data of Banks Listed on the Warsaw Stock Exchange. Copernic. J. Financ. Account. 2014, 3, 33-43. [CrossRef]

88. Bolibok, P. The Relative Value Relevance of Earnings, Boom Values and Cash Flows in the Polish Banking Sector. J. Financ. Manag. Account. 2015, 3, 19-31.

89. Warsaw Stock Exchange Respect Index-Project Description. Available online: http://respectindex.pl/project_description (accessed on 10 June 2021).

90. GPW Benchmark Indices GPW Benchmark. Available online: https://gpwbenchmark.pl/pub/BENCHMARK/files/PDF/opis_ indeksow / IndicesGPWB_1220.pdf (accessed on 10 June 2021).

91. Notoria Serwis Polish Company Financial Statements \& Profiles. Available online: https://www-1emis-1com-10009454v00a5 .han.bg.umcs.edu.pl/cgi-bin/comp_profiles (accessed on 10 June 2021).

92. Brokerage House of Bank Ochrony Środowiska, S.A. Available online: https://info.bossa.pl/pub/metastock/mstock/ (accessed on 10 June 2021).

93. Dougherty, C. Introduction to Econometrics, 5th ed.; Oxford University Press: New York, NY, USA, 2016; ISBN 978-0-19-967682-8.

94. European Parliament and Council Directive 2014/95/EU of the European Parliament and of the Council of 22 October 2014 Amending Directive 2013/34/EU as Regards Disclosure of Non-Financial and Diversity Information by Certain Large Undertakings and Groups. Off. J. Eur. Union 2014, L 330, 1-9. Available online: https:/ / eur-lex.europa.eu/legal-content/EN/TXT/?uri= CELEX\%3A32014L0095 (accessed on 26 June 2021). 
95. European Commission. Communication from the Commission to the European Parliament, the European Council, the Council, the European Economic and Social Committee and the Committee of the Regions "The European Green Deal". 2019. Available online: https:/ / eur-lex.europa.eu/legal-content/EN/TXT/?uri=CELEX\%3A52019DC0640 (accessed on 26 June 2021).

96. Subramanyam, K.R.; Venkatachalam, M. The Role of Book Value in Equity Valuation: Does the Stock Variable Merely Proxy for Relevant Past Flows? Social Science Research Network: Rochester, NY, USA, 1998.

97. European Commission. Commission Regulation (EC), No. 1126/2008 of 3 November 2008 Adopting Certain International Accounting Standards in Accordance with Regulation (EC) No. 1606/2002 of the European Parliament and of the Council. Off. J. Eur. Union 2008, 46, 3-483. Available online: https: / / eur-lex.europa.eu/legal-content/EN/ALL/?uri=celex\%3A32008R1126 (accessed on 26 June 2021). 